\title{
CROSS-SECTIONAL STUDY OF EIMERIA SPP. INFECTION IN THREE ANTELOPE SPECIES (ADDAX NASOMACULATUS, GAZELLA DORCAS AND ORYX DAMMAH) MAINTAINED IN THE SOUSS-MASSA NATIONAL PARK (MOROCCO)
}

\author{
Aissa Saidi ${ }^{1,2, *}$, Rachida Mimouni ${ }^{2}$, Fatima Hamadi², Widade Oubrou ${ }^{3}$ \\ ${ }^{1}$ Office National de Securité Sanitaire des Produits Alimentaires, Morocco \\ ${ }^{2} I b n$ Zohr University, Morocco \\ ${ }^{3}$ Souss-Massa National Park, Morocco \\ *e-mail:aissasaidivet@gmail.com,aissa.saidi@edu.uiz.ac.ma
}

Received: 02.05.2020. Revised: 10.09.2020. Accepted: 15.09.2020.

\begin{abstract}
Eimeria spp. are prevalent specific intestinal protozoa in many host species with a very variable degree of pathogenicity, found worldwide. Wild ruminants are susceptible hosts to such infections; these infections become important especially when held under stressing captivity conditions. We present herein a crosssectional study to estimate the Eimeria spp. prevalence and abundance in three threatened antelope species, namely Gazella dorcas, Oryx dammah, and Addax nasomaculatus reintroduced to Souss-Massa National Park (Morocco) after they disappeared from their natural North African biotope. A total number of 254 faecal samples ( 80 from $A$. nasomaculatus, 81 from $O$. dammah and 93 from G. dorcas) were collected and analysed by the qualitative flotation and the quantitative McMaster methods. The infection prevalence was $36.25 \%, 22.58 \%$, and $29.63 \%$ for A. nasomaculatus, G. dorcas, and $O$. dammah, respectively. The average infection abundance values were $21.25 \pm 4.7,136.56 \pm 52.4$, and $20.37 \pm 5.8$ for $A$. nasomaculatus, $G$. dorcas, and $O$. dammah, respectively. Among the three studied antelopes, G. dorcas was the species that was shedding the highest amount of oocysts. This study should be completed by morphological and molecular characterisation of different Eimeria parasites in each antelope host species.
\end{abstract}

Key words: abundance, coccidian infection, prevalence, Sahelo-Saharan antelopes, threatened species

\section{Introduction}

In addition to macroparasites (e.g., nematodes, trematodes, cestodes) that may be a threat for wildlife health, microparasites like protozoans could also be responsible for parasitic disorders in several animal species. Coccidian parasites consists of several groups of protozoans (Apicomplexa), among them the genus Eimeria spp., which infect several species of vertebrates (Bowman, 2014). Eimeria infections are responsible for severe disease in birds and livestock, inducing large economic losses. The life cycle of Eimeriidae is often homoxenous or facultatively heteroxenous. They are extremely host-specific and the whole development occurs mainly in intestines and in a few cases in other organs (e.g., kidneys, gallbladder) of the host with a very variable pathogenic effect (Upton, 2000). Unlike domestic mammals in which coccidian have been studied widely, for economic reasons, few studies were published about wild mammals' infection by Eimeria. However, Eimeria spp. were isolated from a large number of wild mammals species, including ungulates, insectivores, marsupials, rodents and others, regardless of their health impact (e.g., Samuel et al., 2001).

For wildlife conservation purposes, animals are held under particular conditions of sequestration and space limitations, in captivity (zoos) or in semi-captivity (e.g., national parks and nature reserves), making them vulnerable to many health disorders including parasitic infections, which are relatively exacerbated by both a high animal population density and captivity stress (Thomas et al., 2005; Wobeser, 2007).

Therefore, adopting a combined approach of animal welfare and biodiversity conservation, when dealing with threatened species, forces us to elaborate adequate health management strategies. These strategies should be compatible with the field circumstances by establishing guidelines that indicate when wildlife managers (e.g., conservationists, veterinarians, epidemiologists) should act to resolve health-related problems at different scales, viz. individuals, population and ecosystem levels (Aguirre et al., 2002; Delahay et al., 2009).

This is the case in the Souss-Massa National Park (Agadir, Morocco), where three endangered species of Sub-Saharan antelopes are hosted. They are included on the Red List of threatened species of the International Union for Conservation of Nature (IUCN), namely Gazella dorcas Linnaeus, 1788 classified as «Vulnerable» (IUCN SSC Antelope Specialist Group, 2017), Addax nasomacculatus De Blainville, 1816 classified as «Critically endangered» (IUCN SSC Antelope Spe- 
cialist Group, 2016a), and Oryx dammah Cretzschmar, 1826 classified as «Extinct in the Wild» (IUCN SSC Antelope Specialist Group, 2016b).

Eimeria spp. infections were mentioned in many endangered antelopes species from different Protected Areas around the world, as in some of the latest studies conducted in Oryx dammah from USA (Pauling et al., 2016), Antidorcas marsupialis Sundevall, 1847 from Namibia (Turner et al., 2016), Pantholops hodgsonii Abel, 1826 from China (Cao et al., 2019), Philantomba walteri Colyn et al., 2010 from Nigeria (Omonona et al., 2019).

The current cross-sectional study aimed to estimate Eimeria infection prevalence and abundance in these three antelope species in the Souss-Massa National Park by analysing faecal samples using non-invasive coprological techniques, namely flotation and McMaster egg counting technique.

\section{Material and Methods \\ Study area and animals}

The Souss-Massa National Park (SMNP) is a Protected Area intended for ecological rehabilitation and natural resources conservation. It is located south of the city of Agadir, Morocco $\left(9.666666^{\circ} \mathrm{W}, 30.083333^{\circ} \mathrm{N}\right)$ (Fig. 1). It covers a total area of $338 \mathrm{~km}^{2}$ along the Atlantic coast that also includes the estuaries of the River Souss and the River Massa. In addition to the three antelopes (Addax nasomaculatus, Gazella dorcas, Oryx dammah), the SMNP hosts two threatened bird species, (Geronticus eremita Linnaeus, 1758 and Struthio camelus camelus Linnaeus, 1758), and a diversified endemic flora (e.g., Sideroxylon spinosum L.) (ElBekkay et al., 2013). The population sizes of antelopes in the SMNP were estimated at 230 individuals of $O$. dammah, 440 individuals of $A$. nasomaculatus, and 850 individuals of $G$. dorcas. To avoid hybridisationrelated problems between $A$. nasomaculatus and $O$. dammah, A. nasomaculatus and a part of G. dorcas individuals are sharing a geographic spot, while $O$. dammah and another part of G. dorcas are sharing another geographic spot within the Protected Area.

\section{Sampling methodology}

A total of 254 fresh individual faecal samples (80 from A. nasomaculatus, 81 from $O$. dammah, and 93 from $G$. dorcas) were picked up randomly from the ground between January and July 2015. All samples were labelled, transported immediately to the laboratory, and kept at $+4^{\circ} \mathrm{C}$ until analysed.

\section{Laboratory analyses}

Faecal samples were examined by classical coprological methods, simple tube flotation for qualitative microscopic observation and McMaster method to oocysts per gram (OPG) estimation, using the RVC/FAO guide to veterinary parasitology diagnostics (Gibbons et al., 2014), as described by Hansen \& Perry (1994). Consequently, $4 \mathrm{~g}$ of crumbled faecal samples were added to $56 \mathrm{ml}$ of flotation solution, mixed and filtered before filling tubes and McMaster cells. In this technique, we used 1.27-specific gravity Sheather's sugar flotation solution (Dryden et al., 2010). For McMaster, two chambers $(2 \times 0.15 \mathrm{ml})$ were used for counting under the $10 \times$ objective. The tube flotation observations were done under a microscope, $100 \times$ to $1000 \times$ magnifications, driven by Motic $\AA$ Images Plus 2.0 software for image capture, processing and morphometric analysis.
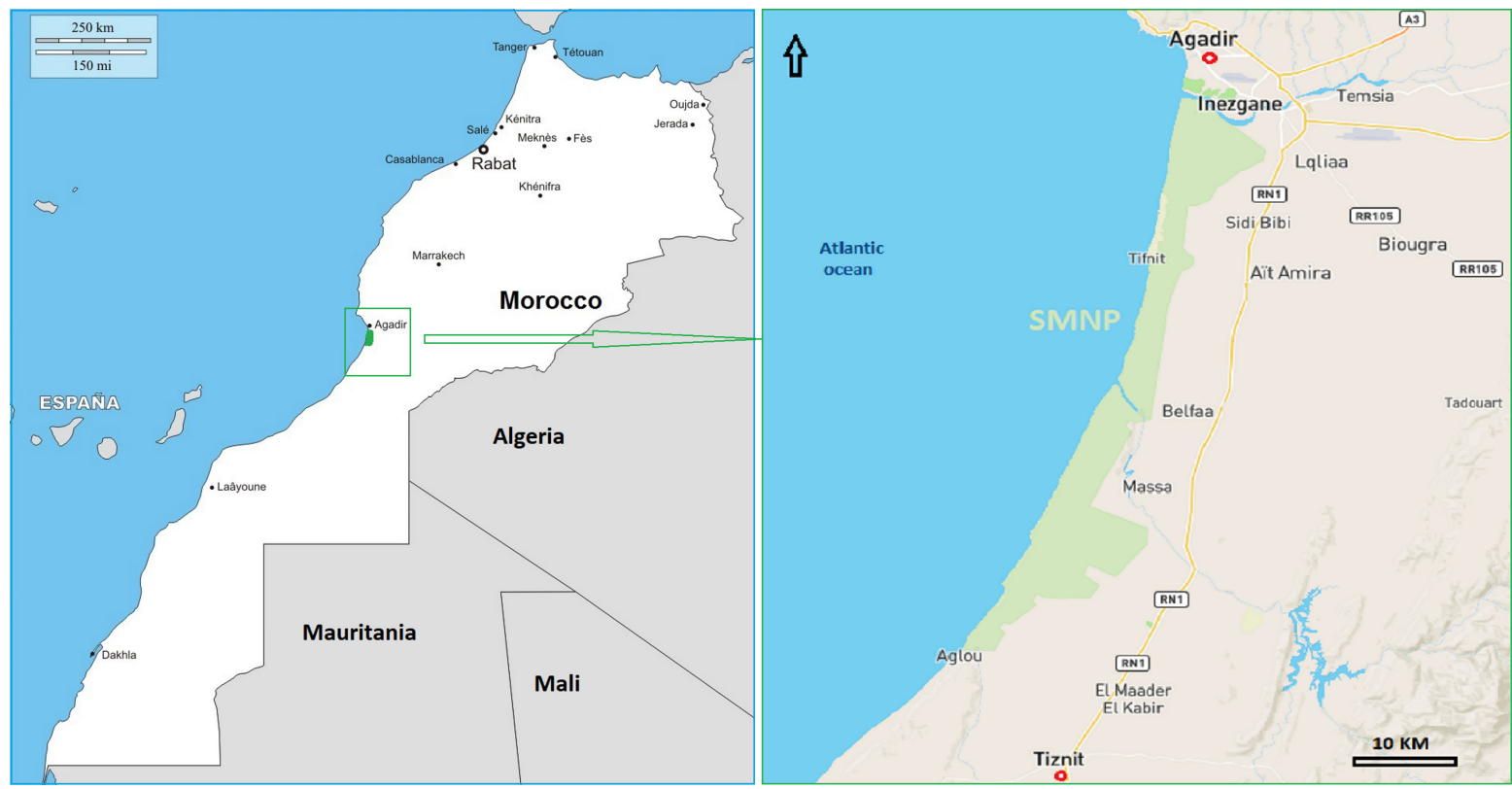

Fig. 1. The localisation and geographical delimitations of the Souss-Massa National Park (indicated in green) in Morocco. 


\section{Statistical analysis}

Two parasitological indicators were estimated. We used the universal parasitological terminology (Bush et al., 1997) and the following formulas:

Infection prevalence $(\%)=100 \times \frac{\text { Number of infected animals }}{\text { Number of examined animals }}$,

Mean abundance $=\frac{\text { Total number of Eimeria spp. oocysts }}{\text { Number of examined animals }}$.

The differences in prevalence were analysed using the $\chi^{2}$ test, parasite infestation abundance among the three antelope populations were compared with one-way analysis of variance (ANOVA) and the Newman-Keuls multiple comparison test at 0.05 threshold value (GraphPad PRISM ${ }^{\circledR}$ v5.00 software, USA). Data are presented as percentages and standard deviation for prevalence, and means \pm mean standard deviation for parasite abundance.

\section{Results and Discussion \\ Infection prevalence}

The infection prevalence of Eimeria infection was estimated to $36.25 \pm 5.40 \%, 22.58 \pm 5.07 \%$, and $29.63 \pm 4.30 \%$ for $A$. nasomaculatus, G. dor$c a s$, and $O$. dammah, respectively (Fig. 3). However, there were no statistically significant differences in Eimeria prevalence between the antelope species $(p>0.05)$.

Three different patterns of Eimeria spp. oocysts were observed: Eimeria sp.1 measuring
$27 \times 16 \mu \mathrm{m}$ from Gazella dorcas (Fig. 2A,B,C), Eimeria sp. 2 measuring $28 \times 21 \mu \mathrm{m}$ from Oryx dammah (Fig. 2D,E), and Eimeria sp.3 measuring $25 \times 20 \mu \mathrm{m}$ from Addax nasomaculatus (Fig. 2F).

\section{Infection abundance}

The infection abundance was statistically higher for Gazella dorcas (136.56 \pm 52.40$)$ compared to Addax nasomaculatus $(21.25 \pm 4.70)$ and Oryx dammah $(20.37 \pm 5.80)(p<0.05)$ (Fig. 3).

The three studied antelopes showed a low mean infection abundance (less than 300 OPG), except for four $G$. dorcas individuals that shed a high number of oocysts (higher than 1000), even though the faecal pellets seem to be normal without any diarrheic aspect.

Infected domestic animals may shed a high amount of oocysts without developing any clinical disorders (Jacobs et al., 2015), and the variation of excreted oocysts could be influenced by several factors. In addition to the parasite species, they can be intrinsic, such as the age of animals (young animals are more vulnerable), hormonal status (corticosteroids), variation in females (increase of oocysts shedding during calving and suckling periods), stress or extrinsic due to environmental conditions related to the animal host population density and breeding conditions (Apio \& Wronski, 2004; Koutny et al., 2012; Bowman, 2014).
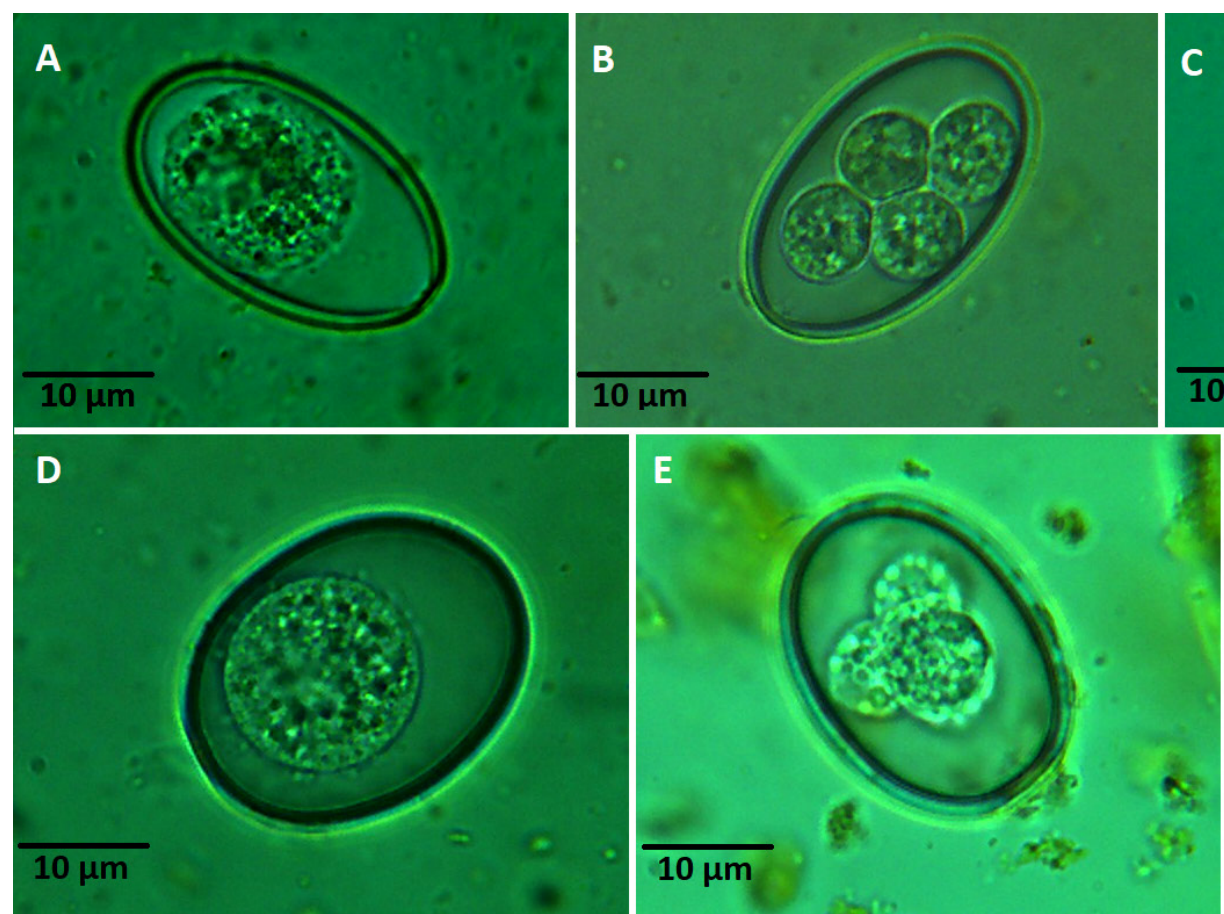
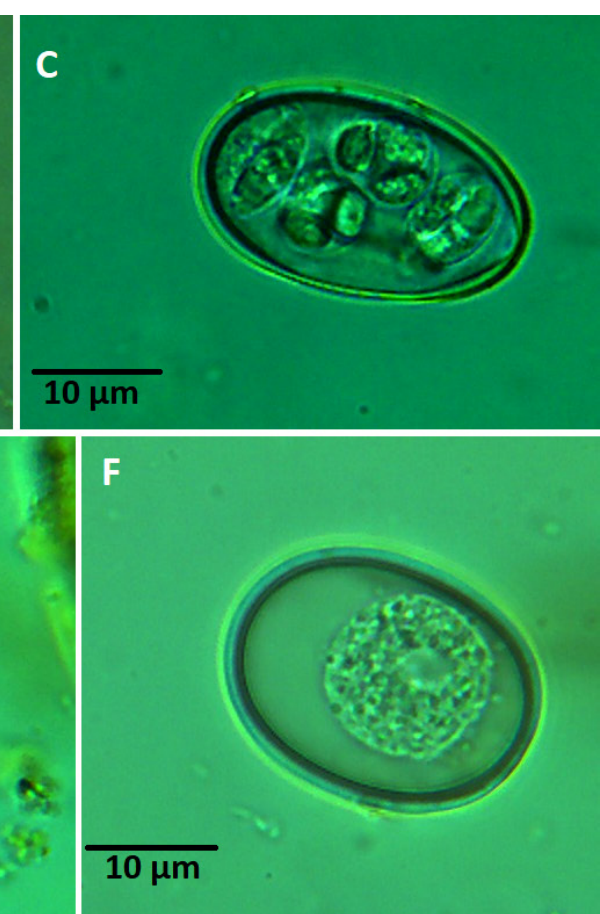

Fig. 2. Different Eimeria spp. oocysts recovered from fecal samples of antelopes in the Souss-Massa National Park (Morocco). Designations: A, D, F-non-sporulated oocysts; B, C, E- sporulated oocysts. 

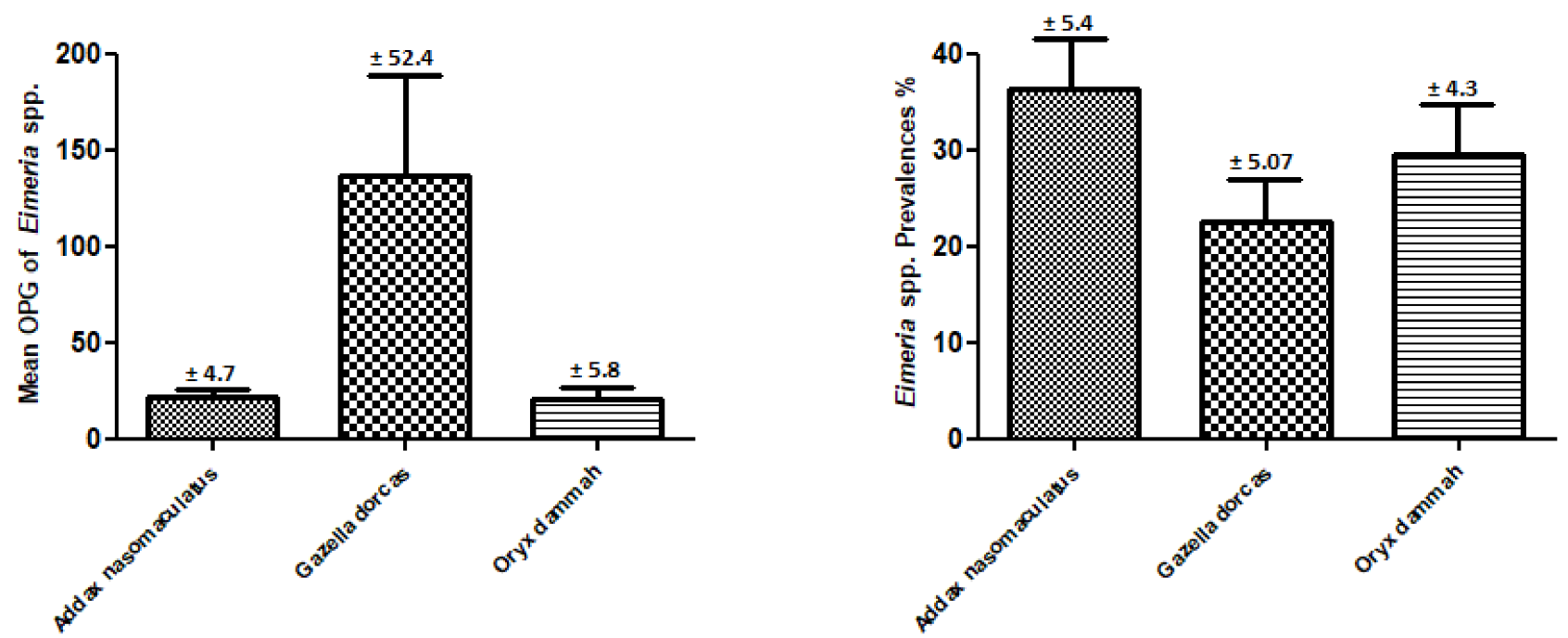

Fig. 3. Eimeria infection abundance (OPG: oocyst per gram in average) (left) and prevalence (right) in the three studied antelopes in the Souss-Massa National Park (Morocco).

Eimeria spp. are worldwide prevalent under diversified conditions of captivity, semi-captivity or free-ranging antelopes. For example, E. dorcadis Mantovani, 1966 infection was reported from $\mathrm{Ga}$ zella dorcas (Mohammed et al., 2012), E. farasanii Omer, Apio, Wronski \& Mohammed, 2011 from Gazella gazella farasani Thouless \& Al-Bassri, 1991 (Omer et al., 2011), E. idmii Mohammed \& Hussein, 1992 from Gazella gazella Pallas, 1766 (Mohammed \& Hussein, 1992), E. rheemi Hussein \& Mohammed, 1992 from Gazella subgutturosa marica Thomas, 1897 (Hussein \& Mohammed, 1992), E. saudiensis Kasim \& Al Shawa, 1988 from Oryx leucoryx Pallas, 1777 (Kasim \& Al Shawa, 1988), E. zuernii (Rivolta, 1878) Martin, 1909 from Oryx dammah (Pauling et al., 2016), infecting also bovines. Eimeria specimens were not determined at species level by some authors, Eimeria sp. from Boselaphus tragocamelus Blainville, 1816 (Singh et al., 2009) and Eimeria sp. from Antilope cervicapra Linnaeus, 1758 (Mir et al., 2016).

The infection abundance varies among previous studies conducted in wild bovids under different circumstances of breeding. For example, Bison bison Linnaeus, 1758 from an Italian zoo was found to shed 500 OPG (Fagiolini et al., 2010); Gazella benetti Sykes, 1831 from an Indian Park shed 2200 OPG (Singh et al., 2006); Beatragus hunteri Sclater, 1889 from a Kenyan wildlife shed 200 OPG (Njeru et al., 2014); Nanger granti Brooke, 1872, Aepyceros melampus Lichtenstein, 1812, Eudorcas thomsonii Günther, 1884 from Kenyan wildlife shed 290, 1160 and 254 OPG, respectively (Ezenwa, 2003).

We emphasise that $G$. dorcas sheds more Eimeria oocysts than the other two studied antelopes.
This could be explained by many factors, such as the animal density, which is a possible extrinsic factor that may correlate positively with the parasite abundance as reported in previous studies (e.g., Tomczuk et al., 2015; Carrau et al., 2018). Among the three animal species, the population size of $G$. dorcas (850 individuals) was much larger than those of $A$. nasomaculatus (440 individuals) and $O$. dammah (230 individuals) with which they share the pasture. which may explain such Eimeria abundance in $G$. dorcas compared to the other two antelope species.

Moreover, the ungulate behaviour influences Eimeria amounts, especially in antelopes as Gazella spp., because they have a more gregarious behaviour than other antelope species (Ezenwa, 2004). In addition, territorial males of gazelles are more likely to have high parasitic infection levels (Ezenwa \& Snider, 2016). Both mentioned behavioural social factors may explain such a high infection levels in G. dorcas.

\section{Conclusions}

An efficient parasitic health management policy in national parks and nature reserves should indeed take into account the health impact of multiple infections. Hence, the excreted amount of oocysts, as a health indicator, should be mentioned together with other faecal excreted forms (helminth eggs and larvae) for gastrointestinal parasitic disease control. Finally, in the light of the foregoing, and due to the seldom-available data on wildlife, especially in those threatened antelopes, we consider to complete the current study by a combined morphometric and molecular characterisation of Eimeria spp. for each antelope species, particularly in Oryx dammah and Addax nasomaculatus populations. 


\section{References}

Aguirre A.A., Richard S.O., Gary M.T., Carol H., Mary C.P. 2002. Conservation Medicine: Ecological health in practice. $1^{\text {st }}$ ed. Oxford: Oxford University Press. 432 p.

Apio A., Wronski T. 2004. Post-parturient changes in faecal helminths egg and coccidian oocyst counts of a bushbuck (Tragelaphus scriptus), Queen Elizabeth National Park, south western Uganda. Helminthologia 41(3): 135-138.

Bowman D.D. 2014. Georgis' Parasitology for Veterinarians-E-Book. $10^{\text {th }}$ Ed. Elsevier Health Sciences. 496 p.

Bush A.O., Lafferty K.D., Lotz J.M., Shostak A.W. 1997. Parasitology Meets Ecology on Its Own Terms: Margolis et al. Revisited. Journal of Parasitology 83(4): 575-583. DOI: 10.2307/3284227

Cao Y.F., Yang Y.B., Duszynski D.W., Zhu Y.H., Zhang T.Z., Shang G.Z., Bian J.H. 2019. Five new species of Eimeria Schneider, 1875 from the endangered Tibetan antelope Pantholops hodgsonii (Abel) (Artiodactyla: Bovidae: Caprinae) in the Hoh Xil Nature Reserve Area of Qinghai Province, China. Systematic Parasitology 96(3): 337-346. DOI: 10.1007/s11230-019-09847-x

Carrau T., Silva L.M.R., Pérez D., Failing K., MartínezCarrasco C., Macías J., Taubert A., Hermosilla C., de Ybáñez R.R. 2018. Associated risk factors influencing ovine Eimeria infections in southern Spain. Veterinary Parasitology 263: 54-58. DOI: 10.1016/j.vetpar.2018.10.004

Delahay R.J., Graham C.S., Michael R.H. 2009. Management of Disease in Wild Mammals. Springer. 284 p. DOI: 10.1007/978-4-431-77134-0

Dryden M.W., Payne P.A., Ridley R., Smith V. 2010. Comparison of common fecal flotation techniques for the recovery of parasite eggs and oocysts. Veterinary Therapeutics 6(1): 15-28.

El-Bekkay M., Moukrim A.I., Benchakroun F. 2013. An economic assessment of the Ramsar site of Massa (Morocco) with travel cost and contingent valuation methods. African Journal of Environmental Science and Technology 7(6): 441-447. DOI: 10.5897/AJEST2013.1485

Ezenwa V.O. 2003. Habitat overlap and gastrointestinal parasitism in sympatric African bovids. Parasitology 126(4): 379-388. DOI: 10.1017/S0031182002002913

Ezenwa V.O. 2004. Host social behavior and parasitic infection: a multifactorial approach. Behavioral Ecology 15(3): 446-454. DOI: 10.1093/beheco/arh028

Ezenwa V.O., Snider M.H. 2016. Reciprocal relationships between behaviour and parasites suggest that negative feedback may drive flexibility in male reproductive behaviour. Proceedings of the Royal Society B: Biological Sciences 283(1831): 20160423. DOI: 10.1098/ rspb.2016.0423

Fagiolini M., Lia R.P., Laricchiuta P., Cavicchio P., Mannella R., Cafarchia C., Otranto D., Finotello R., Perrucci S. 2010. Gastrointestinal parasites in mammals of two Italian zoological gardens. Journal of Zoo and Wildlife Medicine 41(4): 662-670. DOI: 10.1638/2010-0049.1

Gibbons L.M., Dennis E.J., Mark T.F., Hansen J. 2014. The RVC/FAO Guide to Veterinary Diagnostic Parasitolo- gy. Available from https://www.rvc.ac.uk/review/Parasitology/EggCount/Principle.htm

Hansen J., Perry B.D. 1994. Techniques of parasite assays and identification faecal samples, in the epidemiology, diagnosis and control of helminth parasites of ruminants. A handbook. Nairobi, Kenya: ILRAD. 171 p.

Hussein H., Mohammed O. 1992. Eimeria rheemi n. sp. (Apicomplexa: Eimeriidae) from the Arabian sand gazelle, Gazella subgutturosa marica (Artiodactyla: Bovidae) in Saudi Arabia. Journal of the Helminthological Society of Washington 59(2): 190-194.

IUCN SSC Antelope Specialist Group. 2016a. Addax nasomaculatus. In: The IUCN Red List of Threatened Species 2016: e.T512A50180603. Available from http://dx.doi. org/10.2305/IUCN.UK.2016-2.RLTS.T512A50180603.en

IUCN SSC Antelope Specialist Group. 2016b. Oryx dammah. In: The IUCN Red List of Threatened Species 2016: e.T15568A50191470. Available from http://dx.doi.org/10.2305/IUCN.UK.2016-2.RLTS. T15568A50191470.en

IUCN SSC Antelope Specialist Group. 2017. Gazella dorcas. In: The IUCN Red List of Threatened Species 2017: e.T8969A50186334. Available from http://dx.doi.org/10.2305/IUCN.UK.2017- 2.RLTS. T8969A50186334.en

Jacobs D., Fox M., Gibbons L., Hermosilla C. 2015. Principles of Veterinary Parasitology. $1^{\text {st }}$ ed. Wiley-Blackwell. 312 p.

Kasim A.A., Al Shawa Y.R. 1988. Eimeria saudiensis n. sp. (Apicomplexa: Eimeriidae) from the Arabian Oryx (Oryx leucoryx) in Saudi Arabia. Journal of Protozoology 35(4): 520-521. DOI: 10.1111/j.1550-7408.1988.tb04142.x

Koutny H., Joachim A., Tichy A., Baumgartner W. 2012. Bovine Eimeria species in Austria. Parasitology Research 110(5): 1893-1901. DOI: 10.1007/s00436-011-2715-7

Mir A.Q., Dua K., Singla L.D., Sharma S., Singh M.P. 2016. Prevalence of Parasitic Infection in Captive Wild Animals in Bir Moti Bagh Mini Zoo (Deer Park), Patiala, Punjab. Veterinary World 9(6): 540-543. DOI: 10.14202/vetworld.2016.540-543

Mohammed O., Hussein H. 1992. Eimeria idmii n. sp. (Apicomplexa: Eimeriidae) from the Arabian Mountain gazelle, Gazella gazella in Saudi Arabia. Journal of the Helminthological Society of Washington 59(1): 120-124.

Mohammed O.B., Alagaili A.N., Omer S.A. 2012. Redescription of Eimeria dorcadis Mantovani, 1966 (Apicomplexa: Eimeriidae) from the dorcas gazelle (Gazella dorcas) in Saudi Arabia. Folia Parasitologica 59(1): 27-31. DOI: 10.14411/fp.2012.005

Njeru J.M., Kariuki G.M., Andanje E., Wanjala S., Wahungu P.M. 2014. Prevalence and Intensity of Gastrointestinal Parasites in Hirola (Beatragus hunteri) and Livestock in Southern Kenya. African Journal of Education, Science and Technology 1(4): 175-184.

Omer S.A., Apio A., Wronski T., Mohammed O.B. 2011. A new coccidian parasite (Eimeria farasanii n. sp.) indicates parasite-host specificity in endemic Farasan gazelle. International Journal of Zoological Research 7(1): 85-92. DOI: 10.3923/ijzr.2011.85.92 
Omonona A.O., Ademola I.O., Ayansola V.I. 2019. Prevalence of gastrointestinal parasites of Walter's duiker (Philantomba walteri) in Ondo State, Nigeria. African Journal of Biomedical Research 22(1): 73-78.

Pauling C.D., Oller A.R., Jackson V. 2016. Fecal parasite identification by microscopy and PCR in scimitarhorned oryx, Oryx dammah, managed at two sites. International Journal for Parasitology. Parasites and Wildlife 5(3): 312-320. DOI: 10.1016/j.ijppaw.2016.11.001

Samuel W.M., Pybus M.J., Kocan A.A. (Eds.). 2001. Parasitic Diseases of Wild Mammals. Ames: Iowa State University Press. 568 p. DOI: 10.2307/1295958

Singh P., Gupta M.P., Singla L.D., Sharma S., Sandhu B.S., Sharma D.R. 2006. Parasitic Infections in Wild Herbivores in the Mahendra Choudhury Zoological Park, Chhatbir, Punjab. Zoos' Print Journal 21(11): 24592461. DOI: 10.11609/jott.zpj.1519.2459-61

Singh S., Shrivastav A.B., Sharma R.K. 2009. The epidemiology of gastrointestinal parasitism and body condition in free-ranging herbivores. Journal of Threatened Taxa 1(10): 535-537. DOI: 10.11609/JoTT.o1779.535-7
Thomas F., Guegan J.F., Renaud F. (Eds.). 2005. Parasitism and Ecosystems. Oxford: Oxford University Press. 221 p. DOI: 10.1093/acprof:oso/9780198529873.001.0001

Tomczuk K., Grzybek M., Szczepaniak K., Studzińska M., Demkowska-Kutrzepa M., Roczeń-Karczmarz M., Klockiewicz M. 2015. Analysis of intrinsic and extrinsic factors influencing the dynamics of bovine Eimeria spp. from central-eastern Poland. Veterinary Parasitology 214(1-2): 22-28. DOI: 10.1016/j.vetpar.2015.09.027

Turner W.C., Penzhorn B.L., Getz W.M. 2016. Description of 3 new species of Eimeria (Apicomplexa: Eimeriidae) from Springbok (Antidorcas marsupialis) in Namibia. Comparative Parasitology 83(2): 202-211. DOI: $10.1654 / 4831 \mathrm{~s} .1$

Upton S.J. 2000. Suborder Eimeriorina Léger, 1911. In: J.J. Lee, G.F. Leedale, P. Bradbury (Eds.): An Illustrated Guide to the Protozoa. $2^{\text {nd }}$ ed. Vol. 1. Lawrence, KA: Allen Press Inc. P. 318-339.

Wobeser G.A. 2007. Investigation and Management of Disease in Wild Animals. $2^{\text {nd }}$ ed. Springer Science \& Business Media. 265 p. DOI: 10.1007/978-3-540-48978-8

\title{
ИССЛЕДОВАНИЕ ИНФИЦИРОВАНИЯ ВИДАМИ РОДА ЕIMЕRIA TРЕХ ВИДОВ АНТИЛОП (ADDAX NASOMACULATUS, GAZELLA DORCAS И ОRYХ DАММАН) В НАЦИОНАЛЬНОМ ПАРКЕ СУС-МАССА (МАРОККО)
}

\author{
А. Саиди ${ }^{1,2, *}$, Р. Мимуни ${ }^{2}$, Ф. Хамади르, В. Оуброу ${ }^{3}$ \\ ${ }^{1}$ Национальное управление санитарной безопасности пищевых продуктов, Марокко \\ ${ }^{2}$ Университет имени Ибн Зора, Марокко \\ ${ }^{3}$ Национальный парк Сус-Масса, Марокко \\ *e-mail:aissasaidivet@gmail.com,aissa.saidi@edu.uiz.ac.ma
}

\begin{abstract}
Eimeria spp. являются всемирно распространенными специфическими кишечными простейшими у многих видов с очень разной степенью патогенности. Дикие жвачные животные являются восприимчивыми хозяевами к таким инфекциям. Эти инфекции становятся особенно важными, когда животные находятся в стрессовых условиях содержания в неволе. В настоящей работе мы представляем оценку распространенности и численности Eimeria spp. в трех видах антилоп, находящихся под угрозой исчезновения, а именно Gazella dorcas, Oryx dammah и Addax nasomaculatus, реинтродуцированных в национальном парке Сус Масса (Марокко) после их исчезновения в своем естественном биотопе в Северной Африке. В общей сложности 254 пробы фекалий (80 от A. nasomaculatus, 81 от $O$. dammah и 93 от $G$. dorcas) было собрано и проанализировано с помощью методов качественной флотации и количественного метода МакМастера. Степень инфицирования составила $36.25 \%$, $22.58 \%$ и 29.63\% для A. nasomaculatus, G. dorcas и O. dammah, соответственно. Средние значения обилия инфекции составили $21.25 \pm 4.7,136.56 \pm 52.4$ и $20.37 \pm 5.8$ для A. nasomaculatus, G. dorcas и $O$. dammah, соответственно. Среди трех видов антилоп $G$. dorcas отличался наибольшим количеством ооцист. Это исследование должно быть дополнено морфологической и молекулярной характеристикой видов Eimeria у каждого вида-хозяина антилоп.
\end{abstract}

Ключевые слова: кокцидиоз, обилие, сахельско-сахарские антилопы, степень инфицирования, угрожаемый вид 